\section{Online Journalism Ethics}

Traditions and Transitions

Cecilia Friend and Jane B. Singer

\title{
Preocupações éticas para o jornalismo online
}

\author{
FRIEND, Cecília \& SINGER, Jane B. Online journalism ethics: \\ traditions and transitions. New York: M.E.Sharpe. 2007. 246 p.
}

por Rogério Christofoletti

Novos títulos sobre internet e jornalismo digital surgem semanalmente nas prateleiras de livrarias reais e virtuais. A maior parte desses lançamentos chega aos leitores em inglês ou espanhol e se preocupa com a adoção de novos procedimentos técnicos por parte dos jornalistas. Entretanto, outros aspectos mereceriam a atenção de análises mais detidas sobre o impacto de novas tecnologias no universo jornalístico.

Com o advento das redes telemáticas e o desenvolvimento do jornalismo em outras plataformas, mudanças drásticas afetaram as rotinas produtivas, alterando sensivelmente o perfil dos profissionais envolvidos e gerando novos desafios para a prática diária de se produzir e distribuir notícias. A descentralização dos bancos de dados, a predominância da velocidade sobre a correção e a precisão, a disseminação dos mecanismos para interatividade e a convergência das mídias, tudo isso (e mais) trouxe à tona novas e velhas preocupações com a ética. Como lidar com as fontes de informa- ção em situações não-presenciais, quase sempre mediadas ou assistidas por computador? Como desviar-se do anonimato e da falsa identidade de algumas fontes? De que forma devem ser compreendidas e encaradas a privacidade, a verificação das informações e a confiabilidade dos dados obtidos? Existe uma ética específica para jornalistas que trabalham em blogs e portais?

Alguns destes questionamentos orientaram as professoras Cecília Friend e Jane B. Singer em Online journalism ethics: traditions and transitions, editado em 2007 pela M.E.Sharpe. De imediato, a obra chama a atenção pela abordagem do assunto, debruçando-se sobre aspectos ainda explorados insuficientemente nos muitos lançamentos editoriais sobre jornalismo digital. As autoras justificam a escolha feita. É preciso repensar o jornalismo e tentar encaixá-lo num mundo onde qualquer pessoa pode ser seu próprio publisher, onde há muita facilidade e meios para produzir e disseminar informações, onde as mídias tradicionais 
podem ser substituídas por sistemas amorfos e mutantes. Em contextos tão incertos, elas questionam: "Há algum futuro para o que conhecemos por jornalismo?" A hipótese, conforme Friend e Singer, está menos em o que os jornalistas fazem e mais em como fazem e por que assim fazem. A resposta está na dimensão ética da atividade, arriscam as autoras que, numa imodéstia, qualificam a obra como um "livro sobre o futuro do jornalismo".

Dividido em oito capítulos, assinados alternadamente pelas autoras, o livro traz no final de cada um deles estudos de caso que ajudam a dar maior visibilidade aos temas tratados. Friend e Singer apresentam situações e cenários (verdadeiros ou fictícios) envolvendo a prática jornalística, o cotidiano online e os dilemas éticos resultantes de certas condições de produção do jornalista. No final de cada estudo de caso, são lançadas perguntas que estimulam a reflexão sobre a conduta dos jornalistas naquelas circunstâncias espinhosas. Alguns temas são particularmente muito instigantes: Jornalistas online atuam como novos gatekeepers? Em que medida a notícia é uma forma de conversação? Aliás, como trazer os usuários do sistema para o processo de elaboração e difusão informativa? Se a transparência nas fontes de informação é um traço de uma ética emergente para o jornalismo online, deve-se compartilhar todas as informações com o público? Como fica o furo, a informação exclusiva neste contexto? Transparência pode substituir objetividade na gramática do jornalismo?

Mas as perguntas não param por aí. Se blogueiros têm seus próprios métodos e princípios, em que medida blogueiros são jornalistas? Invertendo a situação: jornalistas
Em que medida a notícia é uma forma de conversação? Como trazer os usuários do sistema para o processo de elaboração e difusão informativa? que mantêm blogs, a rigor, são blogueiros? Uma ética para o jornalismo online contempla os valores dos blogueiros? Na blogosfera, credibilidade está diretamente associada à popularidade, mas essa medida é suficiente para o jornalismo online?

Para além de perguntas, Online journalism ethics: traditions and transitions ainda traz como apêndices o Código de Ética da Society of Professional Journalists (SPJ), os Princípios Fundadores da Online News Association e os conceitos-chave de Elementos do Jornalismo, obra de Bill Kovach e Tom Rosenstiel, traduzida no Brasil e já exercendo bastante influência nos meios acadêmicos.

Experientes, as autoras têm trajetórias bem sucedidas na prática jornalística e atualmente se dedicam à docência e pesquisa do campo. Cecília Friend é professora do Utica College, no estado de New York, e Jane Singer atua no Departamento de Jornalismo da University Central Lancashire, no Reino Unido, e na School of Journalism and Mass Communication da University of Iowa, nos Estados Unidos.

Curioso é perceber que a imensa quantidade (e a relevância) dos questionamentos levantados pelas autoras motivou comentários na blogosfera de que a obra trazia mais perguntas que respostas. Isto é, parcelas do meio online já se apropriaram do livro e de seu teor para pensar suas condições. Para um livro de ética profissional, é bem esperado esse resultado mais inquisitivo, problematizador e propositadamente não conclusivo. Mas há luzes de faróis distantes. As autoras acreditam que algumas respostas passam necessariamente pelo desenvolvimento da internet e pela evolução das narrativas em multiplataformas, no próprio processo 
de convergência de meios. Jornalistas serão ainda muito requisitados diante do universo cada vez mais infinito de informações. Mas sua permanência no cenário depende do quão serão confiáveis as informações que oferecerem aos públicos. Isso não é bem uma novidade para o jornalismo, e pelo jeito ainda causará muita insônia nos próximos anos.

Recebido em 3 de março de 2008 Aprovado em 28 de abril de 2008

\section{Sobre $\bullet$ autor}

Rogério Christofoletti, Doutor em Ciências da Comunicação (USP), professor de Legislação e Ética em Jornalismo da Univali, Coordenador do Monitor de Midia (http:// www.univali.br/monitor) e da Rede Nacional de Observatórios de Imprensa (Renoi). email: rogerio.christofoletti@uol.com.br 